\title{
The cellular composition of the granulocyte series in the normal human bone marrow according to the volume of the sample
}

\author{
C. DRESCH ${ }^{1}$, A. FAILle, O. POIRIER, AND J. KADOUCHE
}

From the Service de Médecine Nucléairs, Institut de Recherche sur les Maladies du Sang, Hôpital Saint-Louis, Paris, France

SYNOPSIS The cellular composition of the granulocytic series in normal human bone marrow was studied in aspirates of different volume. An increase in the proportion of polymorphonuclears was observed in samples of more than $1 \mathrm{ml}$, thus indicating a dilution of bone marrow by peripheral blood. Certain data from the literature, referring to the differential count in the bone marrow granulocytic series, are discussed. The differences between these data can be explained by the dilution of bone marrow cells by mature granulocytes in blood.

An exact knowledge of the cellular composition of bone marrow samples used for various kinetic studies, eg, estimation of the granulocytic maturation time and stem cell studies using a bone marrow culture technique, is a necessary requirement for accurate data. However, the classification of normal bone marrow granulocytes in different cell types varies considerably from one author to the other: recent data on granulocyte differential counts are given in the table. Presumably, these differences could be due to the dilution of bone marrow cells by

${ }^{1}$ Correspondence to: Doctor Catherine Dresch, maitre de Recherches, INSERM, Laboratoirz, de Médecine Nucléaire, Centre Hayem, Hôpital Saint-Louis, 2, Place du Docteur-Fournier, 75475, Paris, Cedex 10.

Received for publication 23 October 1973. mature granulocytes in blood. Comparing his own data on granulocyte precursors in bone marrow witlo those of Platt (1969), Northup, Bull, and Carbone (1972) estimated that the extent of dilution of a $\mathrm{ml}$ marrow aspirate with peripheral blood is not excessive. On the other hand, comparing the cellular composition of $2 \mathrm{ml}$ volumes of bone marrow aspirates and rib biopsies, Harrisson (1962) found a significant dilution effect, with an increase in the percentage of polymorphonuclears in the bone marrow aspirates.

Methods

We have studied both the total cell count and the

\begin{tabular}{|c|c|c|c|c|c|c|c|c|c|}
\hline \multirow[t]{3}{*}{ Cell } & \multicolumn{9}{|l|}{ Series } \\
\hline & $\begin{array}{l}\text { Wintrobe } \\
\text { (1967) }\end{array}$ & $\begin{array}{l}\text { Flandrin } \\
(1971)\end{array}$ & $\begin{array}{l}\text { Donohue } \\
\text { (1958) }\end{array}$ & $\begin{array}{l}\text { Harrison } \\
\text { (1962) }\end{array}$ & $\begin{array}{l}\text { Boll } \\
(1970)\end{array}$ & $\begin{array}{l}\text { Cronkite } \\
(1971)\end{array}$ & $\begin{array}{l}\text { Uchida } \\
(197 I)\end{array}$ & $\begin{array}{l}\text { Kurnick } \\
(1971)\end{array}$ & $\begin{array}{l}\text { Northup } \\
\text { (1972) }\end{array}$ \\
\hline & Aspirate $^{1}$ & Aspirate $^{2}$ & $\begin{array}{l}\text { Surgical } \\
\text { Biopsy }\end{array}$ & $\begin{array}{l}\text { Surgical } \\
\text { Biopsy }\end{array}$ & Aspirate & Aspirate & Aspirate & Aspirate & Aspirate $^{\mathrm{3}}$ \\
\hline $\begin{array}{l}\text { Myeloblasts } \\
\text { Promyelocytes } \\
\text { Myelocytes } \\
\text { Metamyelocytes } \\
\text { Polynuclears }\end{array}$ & $\begin{array}{c}3 \cdot 3(0 \cdot 5-8 \cdot 2) \\
8 \cdot 2(1 \cdot 6-13 \cdot 2) \\
19 \cdot 7(18 \cdot 2-31 \cdot 2) \\
36 \cdot 1(21 \cdot 3-52 \cdot 5) \\
32 \cdot 7(11 \cdot 5-49 \cdot 2)\end{array}$ & $\begin{array}{l}5 \pm 3 \\
10.8 \pm 4.6 \\
19.4 \pm 4.3 \\
26.8 \pm 4.1 \\
38 \pm 7.9\end{array}$ & $\begin{array}{r}0 \cdot 5 \\
1 \cdot 3 \\
22 \cdot 4 \\
23 \cdot 3 \\
52 \cdot 5\end{array}$ & $\begin{array}{r}2 \cdot 9 \\
2 \cdot 7 \\
22 \cdot 3 \\
48 \cdot 7 \\
23 \cdot 4\end{array}$ & $\begin{array}{l}4 \cdot 9 \\
13 \\
25 \cdot 5 \\
15 \cdot 2 \\
41 \cdot 4\end{array}$ & $\left.\begin{array}{l}0.4 \\
1 \cdot 2 \\
19 \cdot 5 \\
15 \cdot 7 \\
63 \cdot 2\end{array}\right\}$ & $\begin{array}{r}3 \cdot 3 \\
6 \cdot 9 \\
9 \cdot 2 \\
80 \cdot 6\end{array}$ & $\begin{array}{r}\left.\begin{array}{r}3 \cdot 1 \\
6 \cdot 2 \\
10 \cdot 2\end{array}\right\} \\
80 \cdot 5\end{array}$ & 55 \\
\hline
\end{tabular}

Table Bone marrow granulocyte differential cell count in normal subjects expressed as a percentage of the total number of myeloid cells

${ }^{1}$ Range in brackets.

standard deviation.

sCorrected for likely number of non-granulocytic cells. 
differential granulocyte cell count of the bone marrow in 12 normal subjects. The marrow specimens were obtained by sternal aspiration using a Mallarmé needle (Médica-Scientifique, France). Three to four subsequent samples (each of 0.5 to $1.5 \mathrm{ml}$ ) were withdrawn without moving the needle. The final volume of the aspirate ranged from 2 to $5 \mathrm{ml}$ for each subject.

The number of nucleated cells per ml (counted in a Thomas chamber with two dilutions of $1 / 10$ and $1 / 100$ ) was determined first in each individual sample and a differential count after May-GrünwaldGiemsa staining was made on 500 nucleated cells. The numbers of nucleated cells and the differential

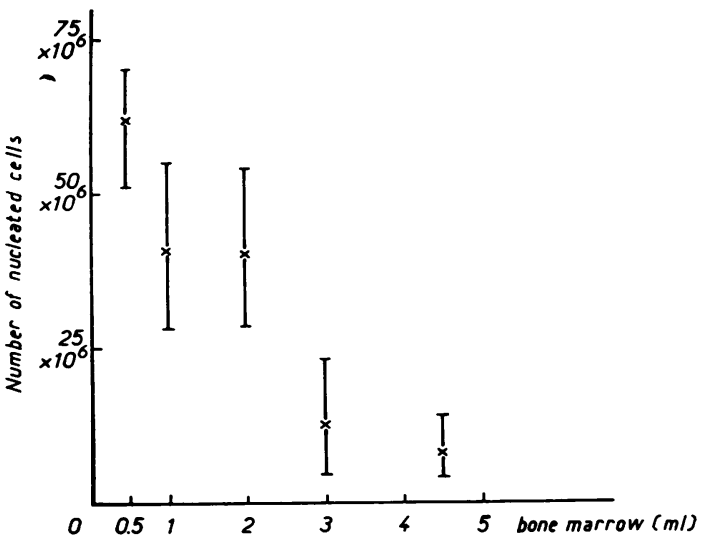

Fig 1 Number of nucleated cells per ml of bone marrow aspirate according to the volume of the sample (mean of 10 to 12 samples \pm range).

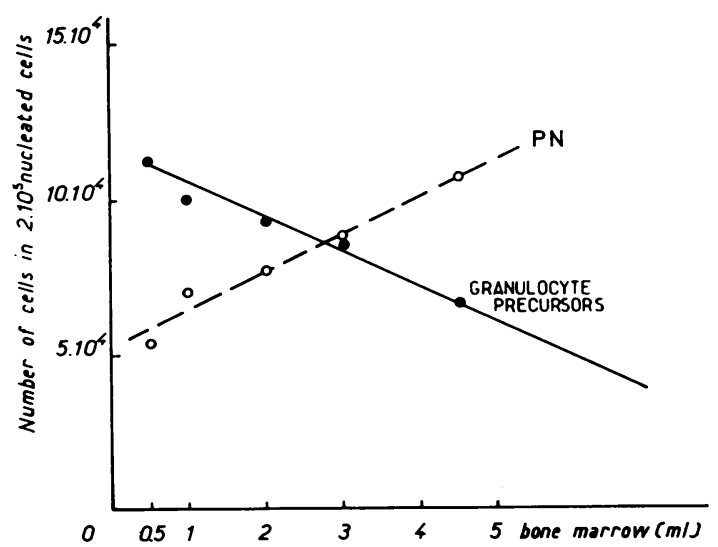

Fig 2 Proportion of granulocyte precursors $(M B+$ $P M+M+M M)$ and polymorphonuclears $(P N)$ in $2.10^{5}$ nucleated cells of bone marrow according to the volume of the sample.

count were then determined by the same technique for a pool of the different samples obtained from each subject: for the two first aspirates mixed together, then for the three first aspirates, and eventually, for four aspirates. Each time the total volume of the pool was noted. The data were considered for a given volume of bone marrow corresponding either to the first sample or to a pool of samples.

\section{Results}

As shown in fig 1, the number of nucleated cells

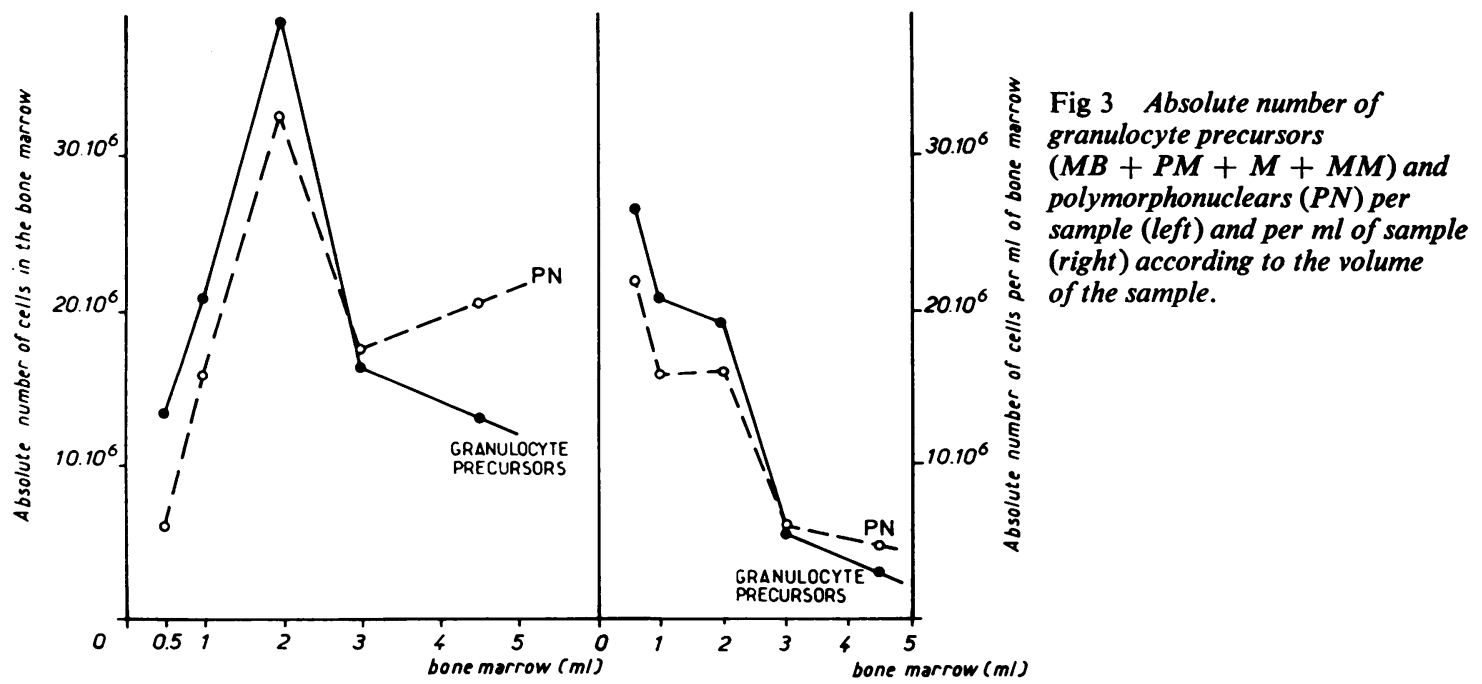


per $\mathrm{ml}$ of bone marrow aspirate fell in proportion to the increase in the sample volume, with the count being very low in samples of more than $3 \mathrm{ml}$.

When differential counts were made (fig 2), the proportion of granulocyte precursors (myeloblaste, promyelocytes, myelocytes, and metamyelocytes) decreased and the proportion of mature polymorphonuclears increased as the volume of the sample became larger.

When the total number of nucleated cells and the differential count are considered (fig 3 ), it can be seen that the number of granulocyte precursors per $\mathrm{ml}$ of bone marrow decreases, but that their absolute number per sample increases, until a $2 \mathrm{ml}$ volume of aspirate is reached. When the sample is more than $2 \mathrm{ml}$ the absolute number of granulocyte precursors per sample decreases.

\section{Discussion}

Comparison of our data with previous figures (see table) indicates that differences in published figures for granulocyte differential counts in normal bone marrow are due to a dilution of marrow by peripheral blood. Wintrobe (1967), Flandrin, Varet, and Ponthus (1971), and Boll and Fuchs (1970), using a few drops of bone marrow aspirate for cytological studies, agree with Harrisson's data (1962) based on rib biopsies in haematologically normal subjects. The percentage of polymorphonuclears reported by these authors ( 23 to $41 \%$ ) are similar to ours $(25$ to $36 \%$ ) when bone marrow samples of less than $1 \mathrm{ml}$ are considered.

The data of Donohue, Reiff, Hanson, Betson, and Finch (1958), also based on rib biopsies, show a higher percentage of polymorphonuclears. However, these studies were carried out on patients submitted to thoracotomy for tuberculosis and, presumably, the number of mature granulocytes was increased by the infectious process.

Northup's data (Northup et al, 1972), based on $4 \mathrm{ml}$ bone marrow aspirates, are similar to our own for the same volume $(58 \%)$ as are the data of
Kurnick, Robinson, and Dickey (1971) on 5 to 10 ml samples. Cronkite and Vincent (1970) and Uchida (1971) do not indicate the volume of the bone marrow aspirates they used for radioautographic studies. Their data are similar to our own for 4 to $6 \mathrm{ml}$ aspirates $(65 \%)$.

From the variations in the cellular composition of bone marrow aspirates of increasing volume, three facts may be emphasized: (1) Even in low volume bone marrow aspirates, dilution by peripheral blood cannot be avoided. (2) Conclusions from kinetic studies which are based on the number of mature granulocytes in bone marrow aspirates, such as the estimation of granulocytes stores and transit time in marrow, should be interpreted with caution. (3) Bone marrow studies which express results as a function of the bone marrow cellularity or volume, such as bone marrow cultures in vitro, should be made on specimens as small as possible and, ideally, on bone marrow samples of less than $2 \mathrm{ml}$ drawn by a single puncture.

\section{References}

Boll, I. T. M., and Fuchs, G. (1970). A kinetic model of granulocytopoiesis. Exp. Cell Res., 61, 147-152.

Cronkite, E. P., and Vincent, P. C. (1970). Granulocytopoiesis. In Hemopoietic Cellular Proliferation, edited by F. Stohlman, ppO 211-228. Grune and Stratton, New York.

Donohue, D. M., Reiff, R. H., Hanson, M. L., Betson, Y., and Finch C. A. (1958). Quantitative measurement of the erythrocytic an granulocytic cells of the marrow and blood. J. clin. Invest., 37?्+ 1571-1576.

Flandrin, G., Varet, B., and Ponthus, J. M. (1971). Etude Statistique de la Méthodologie de Lecture des Myélogrammes Normaux. Sema (Metra International), Paris.

Harrisson, W. J. (1962). The total cellularity of the bone marrow in man. J. clin. Path., 15, 254-259.

Kurnick, J. E., Robinson, W. A., and Dickey, C. A. (1971). In vitro granulocytic colony-forming potential of bone marrow from patients with granulocytopenia and aplastic anemia. Proc. Soc. exp. Biol. (N.Y.), 137, 917-920.

Northup, J. D., Bull, J. M., and Carbone, P. P. (1972). Proliferative activity of human granulocytes, as estimated quantitatively by 'in vitro' colony formation. J. nat. Cancer Inst., 48, 629-637.

Platt, W. R. (1969). Color Atlas and Textbook of Hematology. Lippincott, Philadelphia.

Uchida. T. (1971). Leukokinetic studies in peripheral blood. I. Neutrophilic granulocyte kinetics in normal man. Acta haemat. jap., 34, 164-185.

Wintrobe, M. (1967). Clinical Hematology, 6th ed., p. 38. Lea and Febiger, Philadelphia, Kimpton, London. 